\title{
Construction of Amylolytic Industrial Strains of Saccharomyces cerevisiae for Improved Ethanol Production from Raw Starch
}

\author{
Young-Kum Im ${ }^{1}$, Jin-Yeong Park ${ }^{1}$, Ja-Yeon Lee ${ }^{1}$, Seung-Hyun Choi ${ }^{1}$, \\ Jong-Eon Chin ${ }^{2}$, Hyun-Mi Ko ${ }^{3}$, Il-Chul Kim ${ }^{1}$, and Suk Bai ${ }^{1 *}$ \\ ${ }^{1}$ Department of Biological Sciences, College of Natural Sciences, Chonnam National University, \\ Gwangju 500-757, Republic of Korea \\ ${ }^{2}$ Department of Cosmetology, Dongkang College, Gwangju 500-714, Republic of Korea \\ ${ }^{3}$ Department of Microbiology, College of Medicine, Seonam University, Namwon 590-711, Republic of Korea
}

\section{생전분으로부터 에탄올 생산이 증진된 전분 분해성 산업용 Saccharomyces cerevisiae의 개발}

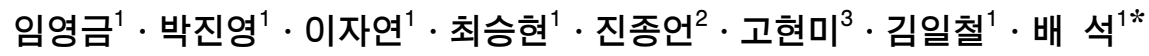 \\ ${ }^{1}$ 전남대학교 자연과학대학 생물학과, ${ }^{2}$ 동강대학 뷰티미용과, ${ }^{3}$ 서남대학교 의과대학 미생물학교실
}

(Received June 3, 2013 / Accepted June 21, 2013)

\begin{abstract}
To contruct amylolytic industrial strains of Saccharomyces cerevisiae which produce ethanol efficiently from raw starch, the Bacillus amyloliquefaciens a-amylase genes (Amy) or Aspergillus awamori glucoamylase genes (GA1) was separately introduced into the ribosomal DNA loci in the chromosomes of the raw starch fermenting-parental

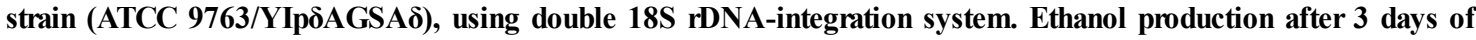
fermentation by the strain that produced ethanol most efficiently from raw starch (ATCC 9763/YIp $\delta$ AGSA $\delta$ /YIpAG2rD) among the transformant strains was 1.5-times higher than that by the parental strain. This new strain generated $9.2 \%(\mathrm{v} / \mathrm{v})$ ethanol $(72 \mathrm{~g} / \mathrm{L})$ from $20 \%(\mathrm{w} / \mathrm{v})$ raw com starch and consumed $75 \%$ of the raw starch content during the same period.
\end{abstract}

Keywords: ethanol production, industrial Saccharomyces cerevisiae, raw starch

The yeast Saccharomyces cerevisiae, which has traditionally been used for industrial ethanol production cannot utilize starch as a carbon source because of its lack of endogenous amylolytic enzymes. Starch biomass for ethanol production needs a two-step pretreatment process, namely, liquefaction and saccharification. Raw starch also needs to be gelatinized by cooking at a high temperature, and then liquefied by $\alpha$-amylase (Eksteen et al., 2003). Raw starch degrading enzymes (RSDE) refer to amylases that can hydrolyze raw starch directly, without an additional high energy-consuming process, such as gelatinization (Shigechi et al., 2004). Many genes of filamentous fungi and yeasts that encode for RSDE have been previously expressed in S. cerevisiae (Sun et al., 2010). A recombinant $S$. cerevisiae that could synthesize and secrete

*For correspondence. E-mail: sukbai@chonnam.ac.kr; Tel.: +82-62-5303412; Fax: +82-62-530-3409
RSDE efficiently might be used to simplify the process and to reduce the costs of ethanol production from raw starch. For industrial-scale fermentation, ethanol productivity from raw starch depends on the improvement of amylase activities (Yamada et al., 2009, 2010). Manipulation of S. cerevisiae to expresses high RSDE activities, via $\delta$-integration and rDNA-integration of the RSDE genes, can be useful for the improvement of ethanol productivity from raw starch (Kim et al., 2011; Yamada et al., 2012). We recently constructed $\delta$ -integrative and rDNA-integrative vectors to allow for the multiple integration of amylase genes into the chromosomes of industrial strains (Ghang et al., 2007; Kim et al., 2010). In this study, we constructed $18 \mathrm{~S}$ rDNA-integrative vectors containing RSDE genes, such as Bacillus amyloliquefaciens $\alpha$-amylase (Amy) and Aspergillus awamori glucoamylase genes (GA1), and integrated them into the RSDE-producing parental strain with $\delta$-integrated $G A 1$ and Debaryomyces occidentalis $\alpha$ 
-amylase (AMY) genes (ATCC 9763/YIp $\delta$ AGSA $\delta$ ) in an effort to develop industrial strains of S. cerevisiae with higher RSDE activities. We investigated the improvement of enzyme activities and of ethanol production from raw starch, using amylolytic yeast strains expressing combinations of GAl, Amy, or $A M Y$, which were constructed by rDNA integration.

Escherichia coli DH5 $\alpha$ was used as the host for transformation and plasmid construction. Bacillus amyloliquefaciens ATCC 23842 was the source of the Amy gene (Gangadharan et al., 2010). ATCC 9763/YIp $\delta A G S A \delta$ was constructed from the industrial strain of S. cerevisiae ATCC 9763 (Kim et al., 2011) and was used as the host for the yeast transformation experiment. Plasmids YIp $\delta A U R A G \delta$ and YIp $\delta A U R S A \delta$ (Ghang et al., 2007) were used as sources of $G A 1$ and $A M Y$ genes, respectively. Plasmid YIpSG2rD (Kim et al., 2010) was employed as the backbone of the rDNA-integrative system. The YPD medium [1\% (w/v) yeast extract, $2 \%(\mathrm{w} / \mathrm{v})$ bacto-peptone, and $2 \%(\mathrm{w} / \mathrm{v})$ glucose] was employed for the propagation of $S$. cerevisiae. Yeast transformants were grown on YPD plates containing aureobasidin A ( $1 \mu \mathrm{g} / \mathrm{ml}$, TaKaRa, Japan) and G418 (300 $\mu$ $\mathrm{g} / \mathrm{ml}$, Sigma, USA), and were then transferred onto YPDS3 plates [YPD containing 3\% (w/v) soluble starch] and incubated for 2 days at $30^{\circ} \mathrm{C}$, after which they were incubated for 2 days at $4{ }^{\circ} \mathrm{C}$. Yeast cells were grown in YPS media $[1 \%(\mathrm{w} / \mathrm{v})$ yeast extract, $2 \%(\mathrm{w} / \mathrm{v})$ bacto-peptone, and $2 \%(\mathrm{w} / \mathrm{v})$ soluble starch] at $30^{\circ} \mathrm{C}$ for 4 days to assay the amylolytic activities present in the culture supernatants. The hydrolysis of raw corn starch was evaluated via the phenol sulfuric acid method as the glucose equivalent (Shigechi et al., 2004). For ethanol fermentation, YPP medium [2\% (w/v) yeast extract, $2 \%(\mathrm{w} / \mathrm{v})$ bacto-peptone, and $0.05 \%(\mathrm{w} / \mathrm{v})$ potassium disulfite] containing $20 \%(\mathrm{w} / \mathrm{v})$ raw corn starch (Sigma) was used (Yamada et al., 2009). Standard DNA manipulations and the Escherichia coli transformation were performed as previously described by Sambrook and Russell (2001). Yeast transformation was carried out via the lithium acetate method as described by Gietz et al. (1992). The Amy gene was amplified by PCR using the oligonucleotides 5' -ACTCCCGGGATGATTCAAAAACGAAAGCGG- $3^{\prime}$ and $5^{\prime}$ -TGTCTAGATTATTTCTGAACATAAATGGAGAC-3'. These primers were designed using the published nucleotide sequences of the B. amyloliquefaciens ATCC 23842 Amy gene (GenBank accession no. GU591658). PCR resulted in $1.5 \mathrm{~kb}$ amplified DNA fragments of the whole open reading frame from genomic DNA of B. amyloliquefaciens ATCC 23842, which underwent digestion with $S m a I$ and $X b a I$, and was then inserted into the same site of YIpSG2rD with deleted GAMI gene, generating YIpBA2rD (Fig. 1). S. cerevisiae ATCC 9763, transformed with YIpBA2rD, was then screened for $\alpha$ -amylase activity on YPDS3 plate. To construct the double 18S
rDNA system containing the $G A 1$ and $A M Y$ genes, $2.1 \mathrm{~kb} G A 1$ gene excised from YIp $\delta$ AURAG $\delta$ and $1.6 \mathrm{~kb} A M Y$ genes excised from YIp $\delta A U R S A \delta$ were inserted into the $S m a \mathrm{I}-X b a \mathrm{I}$ sites downstream of the $A D C l$ promoter $(A D C l p)$ in YIpSG2rD lacking the GAM1 gene, thereby generating YIpAG2rD and YIpSA2rD, respectively (Fig. 1). The glucoamylase and $\alpha$-amylase activities were quantified at $\mathrm{pH}$ 6.0 and $40^{\circ} \mathrm{C}$ using the PGO/ODAD assay (Sigma) and dinitrosalicylic acid method, respectively (Ghang et al., 2007). All assays were repeated in triplicate and the mean values were calculated. Ethanol fermentation was performed using the method described by Ma et al. (2000). In brief, Yeast cells were grown aerobically in $5 \mathrm{ml}$ of YPS medium at $30^{\circ} \mathrm{C}$ in a shaking incubator at $200 \mathrm{rpm}$ for $48 \mathrm{~h}$. The culture was inoculated in $50 \mathrm{ml}$ of YPP containing 20\% (w/v) raw starch in a $100 \mathrm{ml}$ closed flask equipped with a bubbling $\mathrm{CO}_{2}$ outlet, and was incubated at $30^{\circ} \mathrm{C}$ for 6 days with mild agitation at 100 $\mathrm{rpm}$. The culture supernatants were then assayed for ethanol content using a high performance liquid chromatography (HPLC, Waters, USA) using a Rezex ROA organic acid column $(300 \times 7.8 \mathrm{~mm}$, Phenomenex). The operating conditions were $65^{\circ} \mathrm{C}$, water mobile phase, flow rate of $0.6 \mathrm{ml} / \mathrm{min}$, and ethanol concentrations were monitored using a refractive index detector (Waters). Conversion used: 1\% (v/v) ethanol is equivalent to

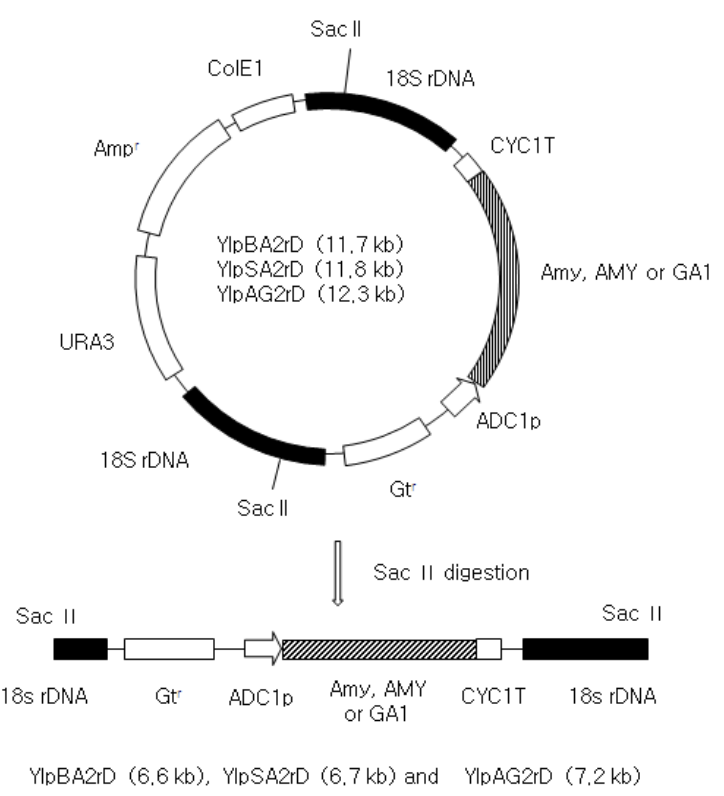

Fig. 1. Plasmid maps of linearized rDNA-integration vectors showing the relative size, restriction sites and locations of the insert DNA. Each rDNA-integration vector was linearized via digestion with SacII. The bacterial vector DNA sequences harboring the ampicillin resistance marker gene and ColE1 (pUC) origin, and $U R A 3$ gene $(5.1 \mathrm{~kb})$ were excised 
Table 1. Glucoamylase and $\alpha$-amylase activities in cell-free culture supernatants of $S$. cerevisiae transformants

\begin{tabular}{|c|c|c|}
\hline Yeast strains & $\begin{array}{c}\text { Glucoamylase activity }^{\mathrm{a}} \\
(\mathrm{U} / \mathrm{ml})\end{array}$ & $\begin{array}{c}\alpha \text {-Amylase activity } \\
(\mathrm{U} / \mathrm{ml})\end{array}$ \\
\hline S. cerevisiae ATCC 9763 & $\mathrm{ND}^{\mathrm{b}}$ & $\mathrm{ND}$ \\
\hline ATCC 9763/YIp $\delta A G S A \delta(G A 1, A M Y)$ & $0.56 \pm 0.04^{\mathrm{c}}$ & $5.82 \pm 0.25$ \\
\hline 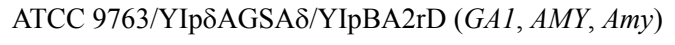 & $0.56 \pm 0.08$ & $6.04 \pm 0.15$ \\
\hline 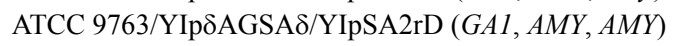 & $0.56 \pm 0.07$ & $6.96 \pm 0.2$ \\
\hline 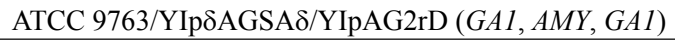 & $1.08 \pm 0.05$ & $5.8 \pm 0.15$ \\
\hline
\end{tabular}

\section{$7.85 \mathrm{~g} / \mathrm{L}$ or $170 \mathrm{mM}$.}

Three vectors containing various amylase genes were linearized by digesting the $18 \mathrm{~S}$ rDNA sequences with SacII, after which the resultant fragments harboring the $A D C 1 p-G A 1$, $A D C 1 p-A m y$ or $A D C 1 p-A M Y$ gene cassettes flanked by the $18 \mathrm{~S}$ rDNA sequences could be integrated into rDNA sequences dispersed throughout the ATCC 9763/YIp $\delta$ AGSA $\delta$ genome to generate multicopy integrants (Nieto et al., 1999). The integrative cassette (YIpBA2rD)-harboring yeast was named ATCC 9763/YIp $\delta A G S A \delta / Y I p B A 2 r D$. The double 18S rDNA system generates a smaller fragment $(5.1 \mathrm{~kb})$ containing unnecessary bacterial sequences excised by digesting SacII before transformation (Fig. 1). The integrative cassettes (YIpAG2rD and YIpSA2rD)-harboring yeasts were designated

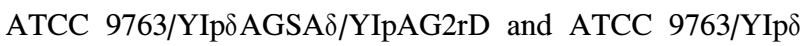
AGSA $\delta / Y I p S A 2 r D$, respectively (Fig. 1). Recently, Kim et al. (2010) reported $\delta$-integrated and rDNA-integrated copy numbers of 46 and 12 for the $\alpha$-amylase and glucoamylase genes, respectively in the recombinant yeast strain exhibiting high $\alpha$-amylase and glucoamylase activity, as determined by real-time PCR analysis. Therefore, the accumulation of sequential $\delta$-integration and rDNA-integration of RSDE genes can result in increasing the copy number of the corresponding genes and improving RSDE activities (Choi et al., 2002). Such stable integrations of DNA containing GA1, Amy, and $A M Y$ genes is expected to facilitate industrial-scale ethanol production from starchy materials in the bioenergy industry (Eksteen et al., 2003).

The recipient parental yeast strain for introducing the linearized 18S rDNA cassettes was ATCC 9763/YIp $\delta$ AGSA $\delta$, which produces ethanol from raw starch due to its relatively strong raw starch-degrading glucoamylase activity (Kim et al., 2011). To examine the effect of rDNA-integration on amylase activities, $\alpha$-amylase and glucoamylase activities were measured in the culture supernatants from transformants grown in YPS media. The clones evidencing the highest levels of activity among the transformants were selected for further analysis. The results (Table 1) show that the $\alpha$-amylase activity of transformant

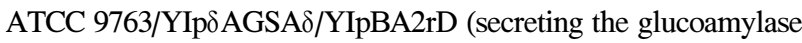
encoded by $A D C 1 p$-GAl and both $\alpha$-amylases encoded by
$A D C 1 p-A M Y$ and $A D C 1 p-A m y)$ was slightly higher than that of the parental strain (ATCC 9763/YIp $\delta$ AGSA $\delta$ ). This result suggests that the secretion of raw starch degrading $\alpha$-amylase from $B$. amyloliquefaciens under its own signal sequences occurred at relatively low levels (Southgate et al., 1993). The activities of $\alpha$-amylase and glucoamylase improved with increasing copy numbers via rDNA-integration (Kim et al., 2010), reaching $6.95 \mathrm{U} / \mathrm{ml}$ and $1.08 \mathrm{U} / \mathrm{ml}$, respectively in ATCC 9763/YIp $\delta A G S A \delta / Y I p S A 2 r D$ and ATCC 9763/YIp $\delta$ AGSA $\delta / Y I p A G 2 r D$. These values were 1.2-times and 1.9-times higher than the respective activities of the parental strain (Kim et al., 2011). The additional multicopy rDNA-integration of the GA1 or $A M Y$ genes can be correlated with the high-level expression of the corresponding genes (Nieto et al., 1999; Choi et al., 2002). The increase in activities of glucoamylase in addition to $\alpha$-amylase is necessary for the more complete degradation of raw starch into glucose units, and consequently, more efficient ethanol production (Shigechi et al., 2004; Sun et al., 2010). Time courses of the cell growth and activities of $\alpha$ -amylase and glucoamylase from ATCC 9763/YIp $\delta A G S A \delta$ /YIpAG2rD were compared with those of the parental strain. As shown in Fig. 2, the activities of $\alpha$-amylase and glucoamylase were growth-associated, reaching maximal levels after 4 days of growth, and no distinct differences in the growth rate and $\alpha$-amylase activity were observed between both strains. However, the rate of increase in glucoamylase activity

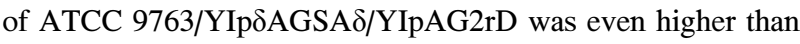
that of the parental strain.

Different recombinant yeast transformants were used for direct ethanol fermentation from $20 \%$ (w/v) raw corn starch under anaerobic conditions. The ethanol productivity from raw starch was improved by increasing the amylase activity, as

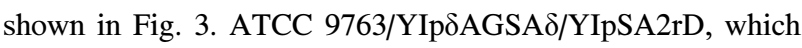
showed 1.2-times higher $A M Y$ activity than the parental strain, generated $7.9 \%(\mathrm{v} / \mathrm{v})$ ethanol after 3 days of fermentation. This value was about 1.3-times higher than the ethanol concentration produced by the parental strain during the same period $[6.2 \%$ (v/v)] (Kim et al., 2011). In contrast, the ability of ATCC

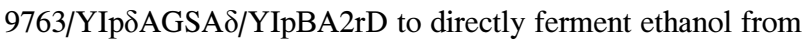
raw starch, which co-produces $G A 1, A M Y$, and $A m y$, was not 


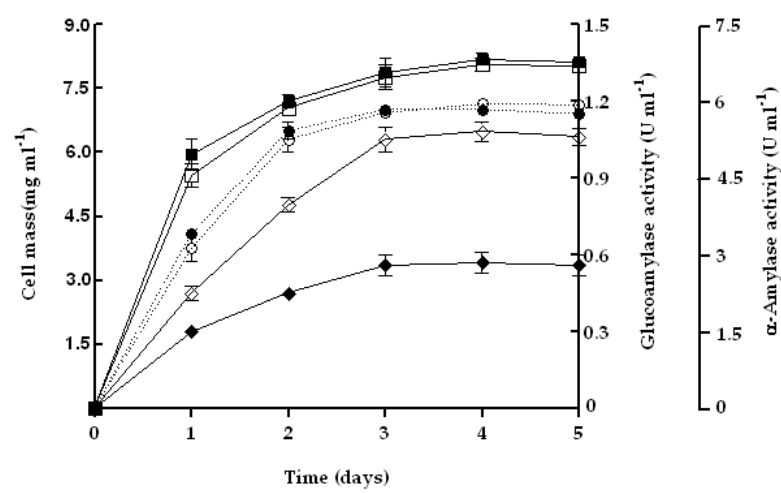

Fig. 2. Growth curve, time courses of extracellular glucoamylase and $\alpha$-amylase activities produced by ATCC 9763/YIp $\delta$ AGSA $\delta$ and

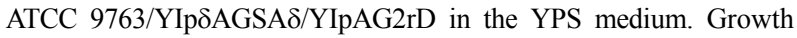
was measured on different days based on the cell dry weight, and glucoamylase and $\alpha$-amylase activities were measured in the culture supernatants. Each point represents the means of three independent measurements. (ם) $\mathrm{mg} / \mathrm{ml}$ cell mass of ATCC 9763/YIp $\delta A G S A \delta$;

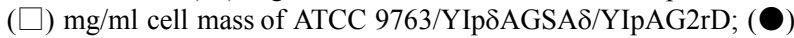
$\mathrm{U} / \mathrm{ml} \alpha$-amylase activities of ATCC 9763/YIp $\delta A G S A \delta ;(\bigcirc) \mathrm{U} / \mathrm{ml} \alpha$

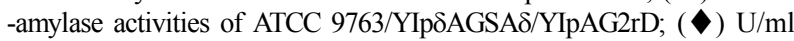
glucoamylase activities of ATCC 9763/YIp $\delta A G S A \delta ;(\diamond) \mathrm{U} / \mathrm{ml}$

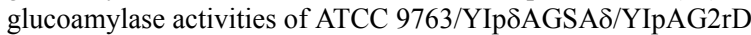

distinctly different from that of the parental strain. Low Amy encoded $\alpha$-amylase activity could not contribute to the improvement of ethanol productivity, although Amy has been identified as RSDE (Gangadharan et al., 2010; Sun et al., 2010). This result indicates that increasing the amylase activity is crucial to efficiently produce ethanol from raw starch (Yamada et al., 2010). On the other hand, ATCC 9763/YIp $\delta$ AGSA $\delta / Y I p A G 2 r D$ generated 9.2\% (v/v) ethanol (72 g/L) after 3 days of fermentation and the ethanol concentration increased gradually and reached a maximum level after 6 days of fermentation. Most of the ethanol was generated after 3 days of fermentation. At this time, the amount of ethanol produced by this strain was 1.5-times higher than that produced by the parental strain. The raw starch content was reduced drastically in inverse proportion to the increase in ethanol concentration during fermentation. Residual starch was determined to be $5 \%$ (w/v) after 3 days of fermentation and 3.6\% (w/v) after 6 days of fermentation, respectively. This result indicates that the increase in the activity of glucoamylase via rDNA integration of the GAl genes results in the improvements of raw starch degradation to glucose and of ethanol fermentation (Nieto et al., 1999). Yamada et al. (2010) has reported that a tetraploid strain of $S$. cerevisiae that secretes Streptococcus bovis a -amylase to hydrolyze raw starch and Rhizopus oryzae glucoamylase produced $70 \mathrm{~g}$ ethanol/L after 3 days of fermentation. The reduction in energy requirements during the

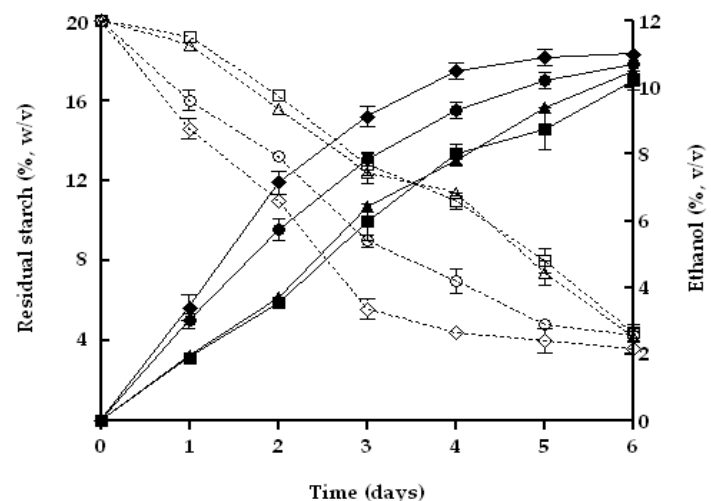

Fig. 3. Time course of ethanol production from raw corn starch by

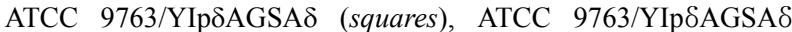

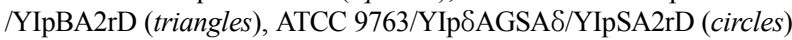
and ATCC 9763/YIpSAGSAS/YIpAG2rD (diamonds). Open and filled symbols show residual starch and ethanol concentrations, respectively. Data are averages from three independent experiments

gelatinization process achieved by using RSDE has been currently exploited for the commercial production of ethanol (Sun et al., 2010). To reduce the costs of ethanol production from raw starch, it may prove necessary to improve the rate of ethanol fermentation by increasing the activities of both raw starch degrading glucoamylase and raw starch degrading $\alpha$ -amylase (Yamada et al., 2012). Concerted efforts by multi-national research teams can be attainable to construct recombinant yeast strains which are capable of converting raw starch to glucose within $48-72 \mathrm{~h}$, to a final ethanol concentration in excess of $10 \%$ in the near future (van Zyl et $a l ., 2012$ ). Further studies are currently underway to increase raw starch-degrading $\alpha$-amylase activity in our expression vector systems for the improvement of ethanol production from raw starch.

\section{적 요}

생전분으로부터 에탄올을 효율적으로 생산하는 전분 분해성 산업용 Saccharomyces cerevisiae 를 제조하기 위해 생전분을 발

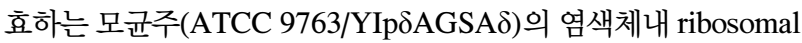
DNA loci에 double $18 \mathrm{~S}$ rDNA-integration 시스템을 이용하여 Bacillus amyloliquefaciens $\alpha$-amylase 유전자(Amy) 혹은 Aspergillus awamori glucoamylase 유전자 $(G A 1)$ 를 다중도입시켰다. 얻어진 형질전환 균주들 중 생전분으로부터 가장 효율적으로 에탄올을

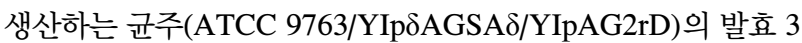
일째 에탄올 생산은 모균주에 비해 1.5 배 높았다. 이 새로운 균 주는 생옥수수 전분이 $20 \%(\mathrm{w} / \mathrm{v})$ 함유된 배지에서 3 일간 발효 를 통해 에탄올 $9.2 \%(\mathrm{v} / \mathrm{v})(72 \mathrm{~g} / \mathrm{L})$ 를 생산하였고, 생전분 함유 량의 $75 \%$ 를 소비하였다. 


\section{Acknowledgements}

Young-Kum Im and Jin-Yeong Park were supported by the second stage of the Brain Korea 21 project.

\section{References}

Choi, E.Y., Park, J.N., Kim, H.O., Shin, D.J., Im, S.Y., Lee, H.B., Chun, S.B., and Bai, S. 2002. Construction of an industrial polyploid strain of Saccharomyces cerevisiae containing Saprolegnia ferax $\beta$ -amylase gene and secreting $\beta$-amylase. Biotechnol. Lett. 24, 17851790.

Eksteen, J.M., van Renseburg, P., Cordero, Otero R.R., and Pretorius, I.S. 2003. Starch fermentation by recombinant Saccharomyces cerevisiae strains expressing the $\alpha$-amylase and glucoamylase genes from Lipomyces kononenkoae and Saccharomycopsis fibuligera. Biotechnol. Bioeng. 84, 639-646.

Gangadharan, D., Ramachandran, P., Paramasamy, G., Pandey, A., and Nampoothiri, K.M. 2010. Molecular cloning, overexpression and characterization of the raw-starch-digesting $\alpha$-amylase of Bacillus amyloliquefaciens. Biologia. 65, 392-398.

Ghang, D.M., Yu, L., Lim, M.H., Ko, H.M., Im, S.Y., Lee, H.B., and Bai, S. 2007. Efficient one-step starch utilization by industrial strains of Saccharomyces cerevisiae expressing the glucoamylase and $\alpha$ -amylase genes from Debaryomyces occidentalis. Biotechnol. Lett. 29, 1203-1208.

Gietz, D., St. Jean, A., Woods, R., and Schiestl, R.H. 1992. Improved method for high efficiency transformation of intact yeast cells. Nucleic Acids Res. 20, 1425.

Kim, H.R., Im, Y.K., Ko, H.M., Chin, J.E., Kim, I.C., Lee, H.B., and Bai, S. 2011. Raw starch fermentation to ethanol by an industrial distiller's strain of Saccharomyces cerevisiae expressing glucoamylase and $\alpha$-amylase genes. Biotechnol. Lett. 33, 16431648 .

Kim, J.H., Kim, H.R., Lim, M.H., Ko, H.M., Chin, J.E., Lee, H.B., Kim, I.C., and Bai, S. 2010. Construction of a direct starch-fermenting industrial strain of Saccharomyces cerevisiae producing glucoamylase, $\alpha$-amylase and debranching enzyme. Biotechnol.
Lett. 32, 713-719.

Ma, Y., Lin, L.L., Chien, H.R., and Hsu, W.H. 2000. Effcient utilization of starch by a recombinant strain of Saccharomyces cerevisiae producing glucoamylase and isoamylase. Biotechnol. Appl. Biochem. 31, 55-59.

Nieto, A., Prieto, J.A., and Sanz, P. 1999. Stable high-copy number integration of Aspergillus orizae $\alpha$-amylase cDNA in an industrial baker's yeast strain. Biotechnol. Prog. 15, 459-466.

Sambrook, J. and Russell, D.W. 2001. Molecular Cloning: A Laboratory Manual. Cold Spring Harbor Laboratory Press, NY, USA.

Shigechi, H., Koh, J., Fujita, Y., Matsumoto, T., Bito, Y., Ueda, M., Satoh, E., Fukuda, H., and Kondo, A. 2004. Direct production of ethanol from raw corn starch via fermentation by use of a novel surface-engineered yeast strain codisplaying glucoamylase and $\alpha$ -amylase. Appl. Environ. Microbiol. 70, 5037-5040.

Southgate, V.J., Steyn, A.J.C., Pretorius, I.S., and van Vuuren, H.J.J. 1993. Expression and secretion of Bacillus amyloliquefaciens $\alpha$ -amylase by yeast pheromone $\alpha$-factor promoter and leader sequence in Saccharomyces cerevisiae. Appl. Environ. Microbiol. 59, 1253-1258.

Sun, H., Zhao, P., Ge, X., Xia, Y., Hao, Z., Liu, J., and Peng, M. 2010. Recent advances in microbial raw starch degrading enzymes. Appl. Biochem. Biotechnol. 160, 988-1003.

van Zyl, W.H., Bloom, M., and Viktor, M. 2012. Engineering yeasts for raw starch conversion. Appl. Microbiol. Biotechnol. 95, 1377-1388.

Yamada, R., Bito, Y., Adachi, T., Tanaka, T., Ogino, C., Fukuda, H., and Kondo, A. 2009. Efficient production of ethanol from raw starch by a mated diploid Saccharomyces cerevisiae with integrated $\alpha$ -amylase and glucoamylase genes. Enzyme Microb. Technol. 44, 344 -349 .

Yamada, R., Tanaka, T., Ogino, C., Fukuda, H., and Kondo, A. 2010. Novel strategy for yeast construction using $\delta$-integration and cell fusion to efficiently produce ethanol from raw starch. Appl. Microbiol. Biotechnol. 85, 1491-1498.

Yamada, S., Yamada, R., Tanaka, T., Ogino, C., and Kondo, A. 2012. Repeated fermentation from raw starch using Saccharomyces cerevisiae displaying both glucoamylase and $\alpha$-amylase. Enzyme Microb. Technol. 50, 343-347. 